\title{
Oceanographic and climatic factors influencing breeding and colony attendance patterns of Humboldt penguins Spheniscus humboldti in central Chile
}

\author{
Alejandro Simeone ${ }^{1, *}$, Braulio Araya $^{2}$, Mariano Bernal $^{3}$, Edward N. Diebold ${ }^{4}$, \\ Karen Grzybowski ${ }^{5}$, Margaret Michaels ${ }^{5}$, J. Andrew Teare ${ }^{6}$, Roberta S. Wallace ${ }^{5}$, \\ Mary Jo Willis ${ }^{7}$ \\ ${ }^{1}$ Institut für Meereskunde, Düsternbrooker Weg 20, 24105 Kiel, Germany \\ ${ }^{2}$ Anakena 2311, Departamento 208, Viña del Mar, Chile \\ ${ }^{3}$ Instituto de Oceanología, Universidad de Valparaíso, Casilla 13-D, Viña del Mar, Chile \\ ${ }^{4}$ Riverbanks Zoological Park and Botanical Garden, PO Box 1060, Columbia, South Carolina 29202, USA \\ ${ }^{5}$ Milwaukee County Zoo, 10001 West Bluemound Road, Milwaukee, Wisconsin 53226, USA \\ ${ }^{6}$ Jacksonville Zoo, 8605 Zoo Parkway, Jacksonville, Florida 32218, USA \\ ${ }^{7}$ Denver Zoological Foundation, 2900 E. 23rd Avenue, Denver, Colorado 80205, USA
}

\begin{abstract}
A colony of Humboldt penguins Spheniscus humboldti in central Chile was monitored from August 1995 to July 2000 to determine patterns of breeding and colony attendance and how these were affected by climatic (rainfall) and oceanographic (El Niño) factors. Nests were periodically checked for contents and roosting birds were counted from vantage points. Two main breeding events were observed: between August and January (spring event) and between April and June (autumn event). Whereas the spring event regularly produced offspring, the autumn event was systematically affected by rains, causing considerable nest desertion. Adults were present in the colony from August to May, abandoning the colony during winter after the nests were flooded. Juveniles occurred only between November and March. Adults moulted mainly in February, while juveniles moulted in January. During the 1997/98 El Niño episode, the number of breeding pairs was 55 to $85 \%$ lower than the mean, the onset of nesting was delayed, and abnormally heavy rainfall flooded nests. While the number of breeding pairs was significantly related to sea surface temperature anomalies (SSTA), breeding success was not. The attendance of adults and juveniles at the colony during El Niño was 25 and $73 \%$ lower, respectively, than the mean attendance. This 2-peak breeding strategy of Humboldt penguins appears to have evolved in response to the more favourable oceanographic and climatic conditions of Perú, where breeding is continuous and not interrupted by rains. Although less productive, the species probably maintains its autumnal breeding in central Chile because this provides additional offspring to supplement those regularly produced during the spring event.
\end{abstract}

KEY WORDS: Humboldt penguin · Spheniscus humboldti $\cdot$ El Niño $\cdot$ Nest desertion · Breeding · Colony attendance

Resale or republication not permitted without written consent of the publisher

\section{INTRODUCTION}

Birds are generally believed to time breeding to coincide with optimal environmental conditions and

*E-mail: asimeone@ifm.uni-kiel.de the seasonal increase in food availability in order to maximize reproductive success, and regional adaptations in breeding seasons have been considered to be the rule (Lack 1954). Seabirds in temperate regions undergo synchronous breeding events once a year during spring and summer, because the period of maximum food availability here tends to be short compared

() Inter-Research $2002 \cdot$ www.int-res.com 
with the tropics where little, if any, seasonal environmental fluctuation occurs and bird breeding may extend over a longer period (Lack 1954, 1967, Furness \& Monaghan 1987). Nearly all marine birds follow this synchrous breeding strategy (Lack 1967).

The Humboldt penguin Spheniscus humboldti breeds over $4500 \mathrm{~km}$ along the Pacific coast of Perú and Chile between $5^{\circ}$ and $42^{\circ} \mathrm{S}$ (Williams 1995). Over this extensive distribution area the species faces considerable latitudinal gradients in oceanographic and climatic factors, including marine productivity, El Niño events, sea surface temperatures and rainfall (see Hunt \& Schneider 1987). This situation is likely to expose the species to differential selective pressures over its breeding range.

In their northernmost breeding areas along the subtropical Peruvian coast, Humboldt penguins nest throughout the year with well-defined breeding events in autumn and spring (Murphy 1936, Zavalaga \& Paredes 1997). Whereas adults remain permanently near the colonies, juveniles are absent for several months after fledging (Zavalaga \& Paredes 1997). This area is characterized by minimal rainfall (FAO 1985) and cold sea temperatures due to intense and persistent upwelling that supports a high sea productivity and large stocks of clupeoid fishes (Ryther 1969, Wooster \& Sievers 1970, Cushing 1978, Rojas de Mendiola 1981). Alterations in these breeding and attendance patterns occur mainly during El Niño events, when anomalously heavy rainfall and food shortage interrupt breeding and force birds to abandon their colonies (Hays 1986, Paredes \& Zavalaga 1998) in search of more productive areas at sea (Culik et al. 2000). Reductions in breeding performance, and changes in distribution and population levels of seabirds due to El Niño are particularly strong along the coasts of Ecuador and Perú (Barber \& Chávez 1983, Tovar \& Guillén 1987, Valle et al. 1987, Duffy 1990).

In central Chile between $32^{\circ}$ and $36^{\circ} \mathrm{S}$, where ca. $20 \%$ of the total Humboldt penguin population is to be found (Ellis et al. 1998), upwelling is relatively lighter and seasonal compared to that in Perú (Wooster \& Sievers 1970, Johnson et al. 1980, Ahumada et al. 1983), rainfall is much higher and concentrated in winter (FAO 1985), and the effects of El Niño on seabird populations are comparatively less severe (Duffy 1990). How do these contrasting climatic and oceanographic conditions affect breeding and colony attendance of Humboldt penguins? What are the effects of El Niño on these variables? Except for census data (Meza et al. 1998), little is known about these factors in central Chile and the extent to which regional adaptations may occur. We hypothesized that, in response to the distinct environmental conditions, both breeding and colony-attendance strategies would differ from those described for Perú. To test this hypothesis, we monitored a colony in Central Chile over 5 consecutive years. We were particularly interested in determining how these strategies were affected by seasonal rains and the 1997/98 El Niño episode.

\section{MATERIALS AND METHODS}

The study was carried out at the Nature Reserve 'Pájaro Niño Island' $\left(33^{\circ} 21^{\prime} \mathrm{S}, 71^{\circ} 41^{\prime} \mathrm{W}\right)$, Algarrobo, one of the 2 largest colonies of Spheniscus humboldti in central Chile (Ellis et al. 1998). This 3 ha island was joined to the mainland in 1977 by a breakwater wall to build a marina. A detailed description and history of the colony is given by Simeone \& Bernal (2000).

From August 1995 to July 2000 we counted nests and roosting birds. The colony was monitored twice per week during the periods of major nesting activity (April/May and October/November) and twice per month during the rest of the year.

Monitoring plots for 3 sections of the colony were established, each partitioned into $10 \times 10 \mathrm{~m}$ grids (total area $=7500 \mathrm{~m}^{2}$ ). The plots were pragmatically selected for ease of counting, safe access and believed representativeness (Bibby et al. 2000). The plots included ca. 300 nests, constituting ca. $45 \%$ of the total number of penguin nests on the island (Simeone \& Bernal 2000). Nests within these grids were asigned with a grid and nest number. Nests were individually checked and considered active if adults, eggs or chicks (or combinations of these) were present. A nest was recorded as abandoned due to rains when, although active on the previous visit, it was found flooded in the following visit with clear signs of abandonment (i.e. absence of adults, wet or muddy eggs, dead chicks).

Direct counts of roosting birds (Bibby et al. 2000) were performed from suitable vantage points located at the highest point of the island (ca. $40 \mathrm{~m}$ height). Counts were conducted with $7 \times 50$ binoculars and a $60 \times$ spotting scope near dusk (18:00 to 20:00 h from October to March and 17:00 to 18:00 h from April to September), when most penguins return to the colony after foraging (see Fig. 1b in Wilson et al. 1995). The shore was divided into 9 counting sections based on the features of the area. Distinction was made between adults and juveniles as well as between moulting and non-moulting birds. Counts were avoided during periods of heavy rains and rough sea as we considered these factors to affect both the accuracy of the counts and the attendance of birds at the colony.

To reveal for fluctuations in the numbers of active nests during each breeding event ( 2 in this species: autumn and spring) during the 5 yr period, we derived 'anomalies' as follows: a seasonal mean was calculated for the number of active nests by, for example, sum- 
ming the numbers of active nests from all 5 autumn events and then dividing by 5 (only the maximum number of nests per event was considered). This mean value was taken to be $100 \%$, and each of the original 5 values was expressed as a difference (in \%) with respect to this mean. The same procedure was followed for the spring events, in addition to examining fluctuations in the numbers of adults and juveniles attending the colony each year.

To document the occurrence of the 1997/98 El Niño episode, we considered the prolonged period of positive sea-surface temperature anomalies (SSTA) to indicate this phenomenom. To relate SSTA to breeding
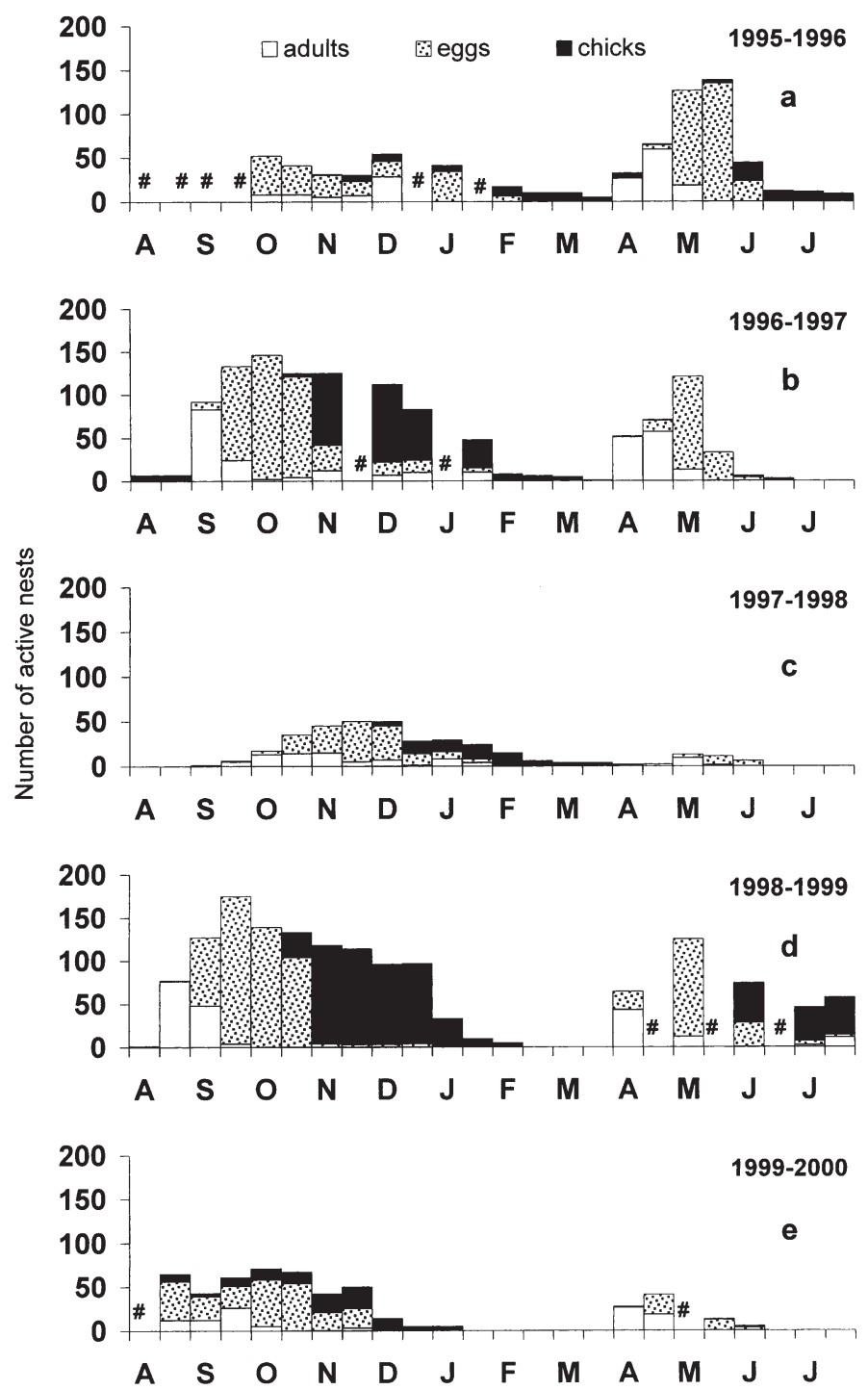

Fig. 1. Spheniscus humboldti. Breeding activity at Pájaro Niño Island, Central Chile, 1995 to 2000. \# = no data. Active nests are those nests containing adults, eggs or chicks, or a combination of any of these activity, we plotted the maximum number of active nests observed during each breeding event against an average SSTA, calculated from the SSTA for the month of maximum breeding activity and the SSTA of the previous month (i.e. April and May for the autumn event, September and October for the spring event). For breeding success (chicks surviving per nest), the same procedure was followed, except that the average SSTA was calculated using values for the whole duration of the event (i.e. from April to July for the autumn event, and September to January for the spring event). Data on breeding success were obtained (R. S. W. unpubl. data). Similarly, we plotted the numbers of birds attending the colony during the periods of highest presence (January and February for adults, December and January for juveniles) against the SSTA values for the respective months.

Data from nesting and roosting birds were grouped into 2 blocks, referred to herein as 'early' (1st to 15 th of each month) and 'late' (16th to 30th of each month). Data on monthly rainfall and SSTA were recorded by the Chilean Navy at Valparaíso, $37 \mathrm{~km}$ north of our area of study.

\section{RESULTS}

\section{Breeding activity}

Within the 12 mo period between August and July, 2 breeding events were observed for Spheniscus humboldti. A spring event occurred mainly between late August and late January (Fig. 1): nest occupation between late August and early September, egg-laying peak in October, and first hatchings between late October and early November. An autumn event occurred between early April and early June (Fig. 1): nest occupation in early April, egg-laying peak in May, and first hatchings in early June. Little breeding activity was observed between February and March and also between late June and early August.

Rains were regularly observed to flood nests during the autumn breeding events, mainly between April and July. During the 1996 and 1997 events, rains (Fig. 2a) flooded and caused the desertion of 86 and $94 \%$ of the active nests, respectively. During these $2 \mathrm{yr}$, flooded nests were more likely to be deserted than non-flooded nests $(2 \times 2$ contingency table, $\mathrm{p}<0.001$, 2 -tailed Fishertest). During 1998, rain fall was low and no flooded nests were recorded. Rains during 1999 accounted for the $47 \%$ of nest desertions; again, flooded nests were more likely to be deserted than non-flooded nests $(2 \times 2$ contingency table, $\mathrm{p}<0.001,2$-tailed Fisher-test). Despite flooding, the 1999 autumn event was the only one that produced significant offspring during the study pe- 



Fig. 2. (a) Monthly rainfall at Valparaíso and (b) monthly sea-surface temperature anomalies (SSTA) off Valparaíso from October 1995 to July 2000

riod (Fig. 1d). During 2000, most nests were already abandoned before the onset of the rains, and only $9 \%$ of desertions were due to flooding; flooded and nonflooded nests were abandoned in similar proportions $(2 \times 2$ contingency table, $p>0.5$, 2-tailed Fisher-test $)$.

Rains were also observed to affect 2 spring breeding events. By the beginning of the 1997 event, most nests were still flooded, and this was likely to have delayed the onset of breeding (Fig. 1c); $8 \%$ of nest desertions was due to flooding, and these nests were more likely to be abandoned than non-flooded nests $(2 \times 2$ contingency table, $\mathrm{p}<0.001,2$-tailed Fisher-test). In 1999, particularly during September (Figs. 1e \& 2a), rains flooded $15 \%$ of the nests, but several birds were able to re-occupy them; both flooded and non-flooded nests were deserted in similar proportions $(2 \times 2$ contingency table, p > 0.05, 2-tailed Fisher-test). The 1995, 1996 and 1998 events were not affected by rains.
An El Niño episode differentially affected 3 nesting events from April 1997 to July 1998 (Fig. 1b,c). This period was characterized by almost continuous positive SSTA and high precipitation (Fig. 2). The onset of the 1997 autumn event was similar to non-El Niño years, but rains caused its failure and delayed the onset of the following spring event for ca. 1 mo. During the $1998 \mathrm{au}-$ tumn event, although conditions were comparatively dry, almost no birds attempted to breed. The breeding seasons during 1997/98 presented the lowest numbers of active nests recorded during the period of study (Table 1), and this variable was negatively related to SSTA $\left(\mathrm{r}^{2}=0.50, \mathrm{p}<0.05, \mathrm{n}=9\right.$; Fig. 3a). Although breeding success was also negatively related with SSTA, this relationship was not significant $\left(\mathrm{r}^{2}=0.50, \mathrm{p}>\right.$ $0.1, \mathrm{n}=6$; Fig. 3b). Nesting was resumed in August 1998, coinciding with the decrease in sea temperature (Figs 1d \& 2b).
Table 1. Spheniscus humboldti. Seasonal number of active nests (mean $\pm \mathrm{SD}$ ) and seasonal anomalies in maximum numbers of active nests (i.e. adults, eggs or chicks present). Anomalies calculated as a function of the seasonal mean (see 'Materials and methods'). nd = no data

\begin{tabular}{|lccccccc|}
\hline \multirow{2}{*}{ Season } & $\begin{array}{c}\text { No. of } \\
\text { active nests }\end{array}$ & $\mathrm{n}$ & \multicolumn{5}{c|}{ Anomalies (\%) } \\
& $(\mathrm{yr})$ & $1995 / 96$ & $1996 / 97$ & $1997 / 98$ & $1998 / 99$ & $1999 / 00$ \\
\hline Spring & $111 \pm 60$ & 4 & nd & +32 & -55 & +58 & -36 \\
Autumn & $88 \pm 57$ & 5 & +57 & +38 & -85 & +42 & -53 \\
\hline
\end{tabular}

\section{Colony attendance}

Adults were regularly present between August and May, with highest attendance always during late February coinciding with the peak in moulting (Fig. 4). Maximum numbers in late February ranged from 1232 

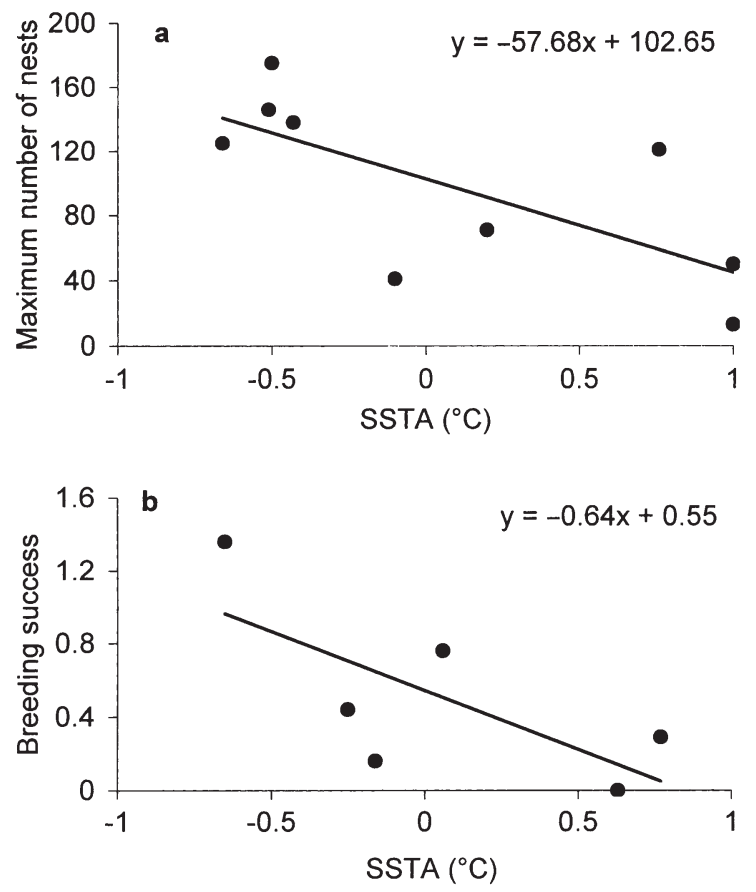

Fig. 3. Spheniscus humboldti. Relationship between (a) maximum number of active nests and SSTA, and (b) between breeding success and SSTA (b). Seasons significantly affected by rains were excluded. See 'Materials and methods' for details

(Fig. 4c) to 1947 (Fig. 4b) individuals. Juveniles were observed only between November and March, with highest attendance always during late January, coinciding with the peak of moult (Fig. 5). Maximum numbers in late January ranged from 65 (Fig. 5c) to 714 (Fig. 5e) individuals.

After rains interrupted breeding, adult birds abandoned their nests and also the colony. Almost no birds were present both inside nests and on the periphery of the colony between June and August (Figs. $1 \& 4$ ).

For both juveniles and adults, the maximum numbers of birds attending the colony during El Niño in January and February 1998, respectively, were the lowest recorded during the period of study (Table 2). Neither adult nor juvenile attendance at the colony

Table 2. Spheniscus humboldti. Yearly number of birds (mean \pm SD) and yearly anomalies in maximum numbers of adults (February) and juveniles (January) attending the colony. Anomalies calculated a function of the yearly mean (see 'Materials and methods')

\begin{tabular}{|lcccccrr|}
\hline \multirow{2}{*}{ Age class } & \multirow{2}{*}{$\begin{array}{c}\text { No. of } \\
\text { birds }\end{array}$} & $\mathrm{n}$ & \multicolumn{5}{c|}{ Anomalies (\%) } \\
& \multicolumn{1}{c}{ (yr) } & 1996 & 1997 & 1998 & 1999 & 2000 \\
\hline Adults & $1636 \pm 264$ & 5 & -4 & +19 & -25 & +3 & +6 \\
Juveniles & $243 \pm 266$ & 5 & -40 & -50 & -73 & -30 & +194 \\
\hline
\end{tabular}
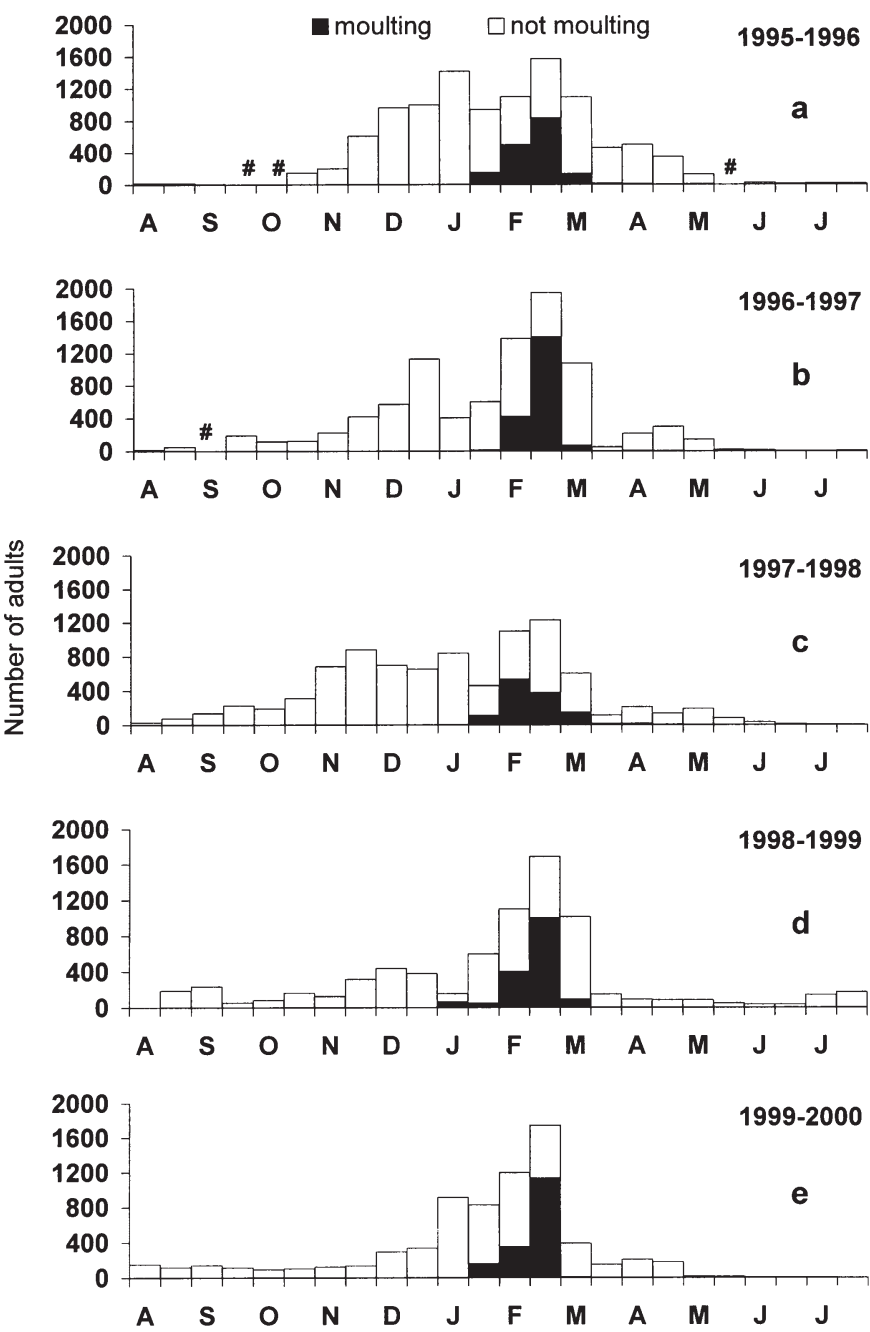

Fig. 4. Spheniscus humboldti. Colony attendance of adults at Pájaro Niño Island, 1995 to 2000. \# = no data

was significantly influenced by SSTA (adults: $\mathrm{r}^{2}=0.04$, $\mathrm{p}>0.5, \mathrm{n}=10$, Fig. $6 a_{\text {; juveniles: }} \mathrm{r}^{2}=0.32, \mathrm{p}>0.05$, $\mathrm{n}=10$, Fig. 6b).

\section{DISCUSSION}

Along the south Peruvian coast, where large colonies of Spheniscus humboldti occur (e.g. Punta San Juan, $15^{\circ} 21^{\prime} \mathrm{S}$; Ellis et al. 1998), the frequent and strong process of ocean upwelling supports a high biomass of phyto- and zooplankton, making the main prey species of the Humboldt penguin (the Pacific sardine Sardinops sagax and the anchovy Engraulis ringens) available throughout the year (Wooster \& Sievers 
Table 3. Spheniscus humboldti. Comparative behavioural features at breeding colonies in southern Perú and central Chile

\begin{tabular}{|c|c|c|}
\hline Feature & $\begin{array}{l}\text { Southern Perú } \\
\left(14 \text { to } 16^{\circ} \mathrm{S}\right)\end{array}$ & $\begin{array}{l}\text { Central Chile } \\
\left(32 \text { to } 36^{\circ} \mathrm{S}\right)\end{array}$ \\
\hline Breeding activity & March-December ${ }^{\mathrm{a}}$ & April-June, August-January \\
\hline Onset of breeding & March, August ${ }^{\mathrm{a}}$ & April, August \\
\hline Laying peak & April, September ${ }^{\mathrm{b}}$ & May, October \\
\hline Moult peak (adults) & Late January ${ }^{\mathrm{a}}$ & late February \\
\hline Adults at the colony & Year round $^{\mathrm{a}^{2}}$ & August-May \\
\hline
\end{tabular}

1970, Rojas de Mendiola 1981). This, coupled with little rainfall $\left(7 \mathrm{~mm} \mathrm{yr}^{-1}\right.$; FAO 1985), favours early nesting and almost continuous breeding (Table 3). On the other hand, the coast of central Chile has a much higher rainfall (351 $\mathrm{mm} \mathrm{yr}^{-1}$; FAO 1985) and upwelling is slighter and seasonal (Wooster \& Sievers 1970, Johnson et al. 1980, Ahumada et al. 1983).

Despite these contrasting conditions, Humboldt penguins at Pájaro Niño attempt to breed after the 'Peruvian'
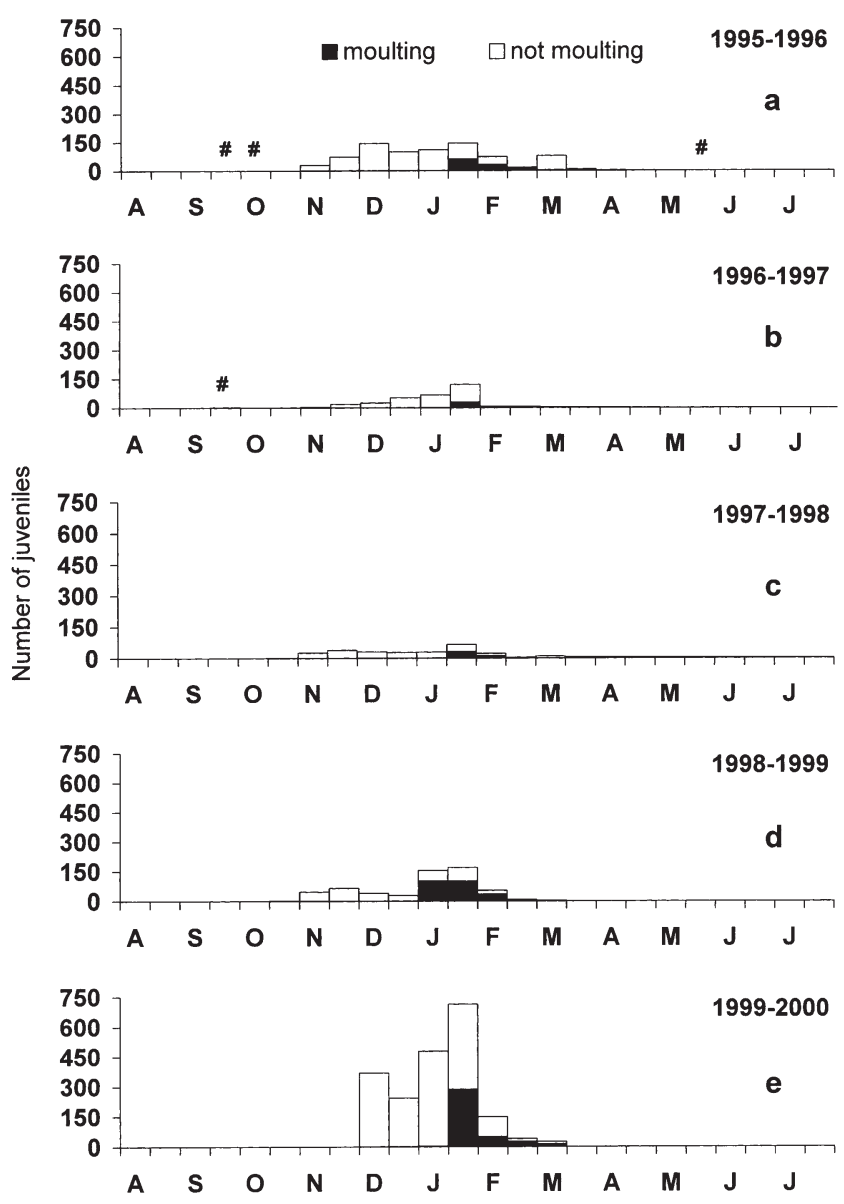

Fig. 5. Spheniscus humboldti. Colony attendance of juveniles at Pájaro Niño Island, 1995 to 2000. \# = no data pattern. As a consequence, the autumn event is regularly affected by rains, resulting in high reproductive failure. A parallel study (R.S.W unpubl.) found that spring breeding events are significantly more successful than autumn breeding events $(0.52$ vs 0.12 chicks per nest). Detrimental and regular consequences of rains during the autumn event have also been reported for Cachagua Island $\left(32^{\circ} 35^{\prime} \mathrm{S}\right), 90 \mathrm{~km}$ to the north of Pájaro Niño (Meza et al. 1998), suggesting a generalized effect along central Chile. At colonies in northern Chile and Perú, flooding is a major cause of nest desertion only during El Niño years (Hays 1986, Vilina 1993, Paredes \& Zavalaga 1998). As no regional adaptation in breeding seems evident, our hypothesis of regional differences is not supported.

During El Niño episodes, the cessation of upwelling and increased sea temperatures (Huyer et al. 1987) decrease the biomass and composition of the phytoand zooplankton (Avaria \& Muñoz 1987, Carrasco \& Santander 1987), affecting reproductive success and the distributions of anchovies and sardines (Cushing 1981, Barber \& Chávez 1983, Alamo \& Bouchon 1987). This causes massive nest desertions, increased adult mortality, and large-scale movements in several seabird species (Vogt 1942, Tovar \& Guillén 1987, Valle et al. 1987). El Niño also causes anomalously heavy rainfall (Rasmusson \& Wallace 1983).

During the 1997/98 El Niño event (one of the strongest on record; Wang \& Weisberg 2000), the comparatively lower number of birds that attempted to breed may have been a response to deteriorating prey availability. Culik \& Luna-Jorquera (1997) found that in periods of strong positive SSTA, the foraging effort of Humboldt penguins increases. At Punta San Juan, Paredes \& Zavalaga (1998) noted abnormally long foraging trips of nesting penguins during January 1998, which was likely to have caused the observed breeding failure. The lack of relation between breeding success and SSTA found in our study may suggest that the few birds that attempted to breed, possibly those more experienced, were able to complete their breeding. The low number of data points $(\mathrm{n}=6)$, however, precludes further discussion. As opposed to this, the periods of comparatively colder waters in 1996 and 1998 (Fig. 2b) that corresponded to La Niña events (Wang \& Weisberg 2000) were linked to the highest number of breeding pairs and successful breeding events.

Flooding of nests due to abnormally heavy rains during this El Niño event was the major cause of nest desertion during the 1997 autumn breeding event and also delayed the onset of the following spring event. 

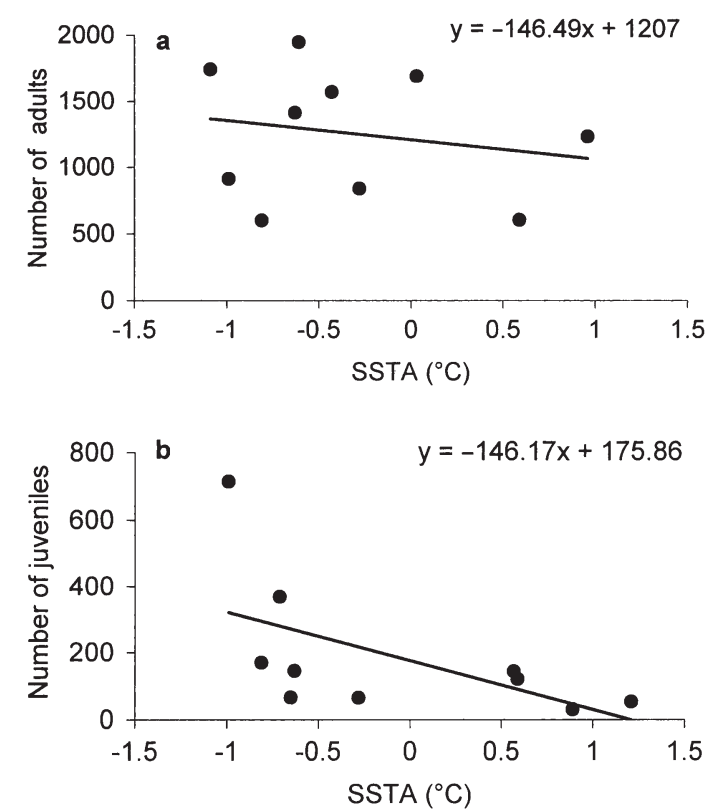

Fig. 6. Spheniscus humboldti. (a) Relationship between number of adults attending the colony and SSTA and (b) between number of juveniles attending the colony and SSTA. See 'Materials and methods' for details

Similar consequences have been reported for this and previous El Niño events at other colonies (e.g. Hays 1986, Vilina 1993, Paredes \& Zavalaga 1998).

The highest attendances of the adult and juvenile Humboldt penguins at Pájaro Niño were 1 mo apart and coincided with the peak in moulting (see Figs 4 \& 5). This temporal separation may hinder aggressive interactions between both age classes (Ryan et al. 1987) and reduce competition for food resources (Adams \& Brown 1990, Boersma et al. 1990). Juveniles apparently return to the colony primarily to moult, as has also been observed in Punta San Juan (Zavalaga \& Paredes 1997) and for the Magellanic penguin Spheniscus magellanicus in Punta Tombo (Boersma et al. 1990). Adult $S$. humboldti in Pájaro Niño moulted 1 mo earlier than adult $S$. humboldti in Punta San Juan (cf. Central Chile and Southern Perú, respectiveley, in Table 3).

In Punta San Juan, Perú, where rainfall is minimal, adult Humboldt penguins remain near the colony throughout the year (Table 3). The absence of adults in the colony during most of the winter in Pájaro Niño seems to be a direct consequence of the rains, which affect the quality of nest sites and force birds to abandon the colony. This marked seasonal absence seems to be a characteristic feature of the population in central Chile.

Although the attendance of both adults and juveniles during January and February 1998 was the lowest observed within the period of study (particularly of juveniles) this does not seem have been influenced by SSTA. While this suggests that despite unfavourable conditions birds must return to the colony to moult, it may be that we also counted birds from other (northern?) colonies that had moved southwards in search of a better food supply (see Culik et al. 2000). The low juvenile counts may not necessarily reflect high mortalily during El Niño, but rather a low breeding success for the previous breeding seasons (see Fig. 1) and thus a lower rate of return to the natal colony.

The high number of breeding pairs and adults observed directly after the 1997/98 El Niño event supports the hypothesis that, rather than dying, birds dispersed to other areas in search of improved conditions (Araya \& Todd 1988, Duffy 1990). Recently, Culik et al. (2000) showed that 2 adult Humboldt penguins in northern Chile were able to travel considerable distances toward areas of higher productivity.

The breeding pattern of the Humboldt penguin appears to have evolved in response to the oceanographic and climatic conditions of Perú, where it was more abundant in the past (Coker 1920, Murphy 1925, 1936). But why do Humboldt penguins still follow the 'Peruvian' strategy in Central Chile and why have they not evolved to seasonal breeders? We propose the following explanation: considering the hypothesis that this species has undergone extralimital dispersal to the south, induced (mainly) by strong El Niño events (Araya \& Todd 1988, Duffy 1990), the maintenance of the 'Peruvian' strategy in a long-lived seabird like the Humboldt penguin, although with lower reproductive success during autumn, would still provide additional offspring to supplement the more productive and regular spring event. This would also reduce the importance of rains as a regulating factor.

Humboldt penguins have nested in central Chile for at least 150 yr (Philippi; in Murphy 1936, p. 461), during which time their breeding strategies have not diverged from those observed in Perú (where the strategy was likely to have evolved), even under the differential selective pressures imposed by climatological and oceanographic factors. This suggests that the strategy may still be advantageous, although it is uncertain if the period in question is sufficient to have allowed divergences in this parameter of life history to evolve.

Acknowledgements. Financial and logistical support was provided by the Zoological Society of Milwaukee County and the Milwaukee County Zoo. The cooperation and interest of the Cofradía Náutica del Pacífico, particularly F. Carlier, was essential to the accomplishment of this study. Climatological data was kindly provided by the Chilean Navy (Armada de Chile) through the Servicio Meteorológico (rainfall) and the Servicio Hidrográfico y Oceanográfico (sea surface temperature anomalies). The Consejo de Monumentos Nacionales permitted work on the island. J. Arata, B. Beehler, S. Lenoe, J. Maurer, C. Pelke, E. Saksefki, V. Salmonese, K. Smith, and J. Zdziarski helped us to collect data over the years. M. Gallardo, S. Garthe, J. Hennicke, G. Luna-Jorquera, R. Wilson 
and 4 anonymous reviewers provided valuable comments on the manuscript. At the time this paper was written, the first author was supported by a grant of the German Academic Exchange Service (DAAD). We thank all of them very much.

\section{LITERATURE CITED}

Adams NJ, Brown CR (1990) Energetics of molt in penguins. In: Davis LS, Darby JT (eds) Penguin biology. Academic Press, San Diego, p 297-315

Ahumada R, Rudolph A, Martínez V (1983) Circulation and fertility of waters in Concepción Bay. Estuar Coast Shelf Sci 16:95-105

Alamo A, Bouchon, M (1987) Changes in the food and feeding of the sardine (Sardinops sagax sagax) during the years 1980-1984 off the Peruvian coast. J Geophys Res 92: $14411-14415$

Araya B, Todd FS (1988) Status of the Humboldt penguin in Chile following the 1982-83 El Niño. Spheniscid Penguin Newsl 1:8-10

Avaria S, Muñoz P (1987) Effects of the 1982-1983 El Niño on the marine phytoplankton off northern Chile. J Geophys Res 92:14 369-14 382

Barber RT, Chávez FP (1983) Biological consequences of El Niño. Science 222:1203-1210

Boersma PD, Stokes DL, Yorio PM (1990) Reproductive variability and historical change of Magellanic penguins (Spheniscus magellanicus) at Punta Tombo, Argentina. In: Davis LS, Darby JT (eds) Penguin biology. Academic Press, San Diego, p 15-43

Bibby CJ, Burgess ND, Hill DA, Mustoe SH (2000) Bird census techniques, 2nd edn. Academic Press, London

Carrasco S, Santander H (1987) The El Niño event and its influence on the zooplankton off Perú. J Geophys Res 92: 14 405-14 410

Coker RE (1920) Habits and economic relations of the guano birds of Perú. Proc US Natl Mus 56:449-529

Culik BM, Luna-Jorquera G (1997) Satellite tracking of Humboldt penguins (Spheniscus humboldti) in northern Chile. Mar Biol 128:547-556

Culik B, Hennicke J, Martin T (2000) Humboldt penguins outmanoeuvering El Niño. J Exp Biol 203:2311-2322

Cushing DH (1978) Upper trophic levels in upwelling areas. In: Boje $\mathrm{R}$, Tomczak $\mathrm{M}$ (eds) Upwelling ecosystems. Springer-Verlag, Berlin, p 101-110

Cushing DH (1981) The effect of El Niño upon the Peruvian anchoveta stock. In: Richards FA (ed) Coastal upwelling. American Geophysical Union, Washington, DC, p 449-457

Duffy DC (1990) Seabirds and the 1982-1984 El Niño-Southern Oscillation. In: Glynn PW (ed) Global ecological consequences of the 1982-83 El Niño-Southern oscillation. Elsevier Oceanogr Ser 52:395-415

Ellis S, Croxall JP, Cooper J (1998) Penguin conservation assessment and management plan. IUCN/SSC Conservation Breeding Specialist Group, Apple Valley, MN

FAO (1985) Agroclimatological data for Latin America and the Caribbean. FAO plant production and protection series No. 24, FAO, Rome

Furness RW, Monaghan P (1987) Seabird ecology. Chapman \& Hall, New York

Hays C (1986) Effects of the 1982-83 El Niño on Humboldt penguin colonies in Perú. Biol Conserv 36:169-180

Hunt GL, Schneider DC (1987) Scale-dependent processes in the physical and biological environment of marine birds. In: Croxall JP (ed) Seabirds, feeding ecology and role in marine ecosystems. Cambridge University Press, Cambridge
Huyer A, Smith RL, Paluszkiewicz T (1987) Coastal upwelling off Perú during normal and El Niño times, 1981-1984. J Geophys Res 92:14 297-14 307

Johnson DR, Fonseca T, Sievers H (1980) Upwelling in the Humboldt Coastal Current near Valparaíso, Chile. J Mar Res 38:1-16

Lack D (1954) The natural regulation of animal numbers. Oxford University Press, Oxford

Lack D (1967) Interrelationships in breeding adaptations as shown by marine birds. In: Snow DW (ed) Proceedings of the XIV International Ornithological Congress. Blackwell Scientific Publications, Oxford, p 3-42

Meza J, Simeone A, García M, Monsalve B (1998) Censos de pingüino de Humboldt (Spheniscus humboldti) en el Monumento Natural Isla Cachagua y Santuario de la Naturaleza Islote Pájaro Niño, 1990-1997. Bol Tec No 66, Corporatión National Forestal, Viña del Mar, p 1-81

Murphy RC (1925) Bird islands of Perú. Putnams, New York

Murphy RC (1936) Oceanic birds of South America. Vol I. American Museum of Natural History, New York

Paredes R, Zavalaga CB (1998) Overview of the effects of El Niño 1997-98 on Humboldt Penguins and other seabirds at Punta San Juan, Perú. Penguin Conservation 11:5-7 (see Araya \& Todd 1988 for journal description)

Paredes R, Zavalaga CB, Boness DJ (2000) Patterns of egg laying and breeding success in Humboldt Penguins (Spheniscus humboldti) at Punta San Juan, Perú. In: LunaJorquera G, Wilson R (eds) Abstracts. Fourth International Penguin Conference, Universidad Católica del Norte, La Serena, Chile, p 28

Rasmusson EM, Wallace JM (1983) Meteorological aspects of the El Niño/Southern oscillation. Science 222:1195-1202

Rojas de Mendiola B (1981) Seasonal phytoplankton distribution along the Peruvian coast. In. Richards FA (ed) Coastal upwelling. American Geophysical Union, Washington, DC, p 349-356

Ryan PG, Wilson RP, Cooper J (1987) Intraspecific mimicry and status signals in juvenile African penguins. Behav Ecol Sociobiol 20:69-76

Ryther JH (1969) Photosynthesis and fish production in the sea. Science 166:72-76

Simeone A, Bernal M (2000) Effects of habitat modification on breeding seabirds: a case study in central Chile. Waterbirds 23:449-456

Tovar H, Guillén V (1987) Reproduction and population levels of Peruvian guano birds, 1980 to 1986. J Geophys Res 92: $14445-14448$

Valle CA, Cruz F, Cruz JB, Merlen G, Coulter MC (1987) The impact of the 1982-1983 El Niño-Southern Oscillation on seabirds in the Galápagos Islands, Ecuador. J Geophys Res 92:14 437-14 444

Vilina YA (1993) Biología reproductiva del pingüino de Humboldt, Spheniscus humboldti Meyen 1834, en isla Chañaral, Chile. MSc thesis, Universidad de Chile, Santiago

Vogt W (1942) Aves guaneras. Bol Cia Adm Guano 18:1-132

Wang C, Weisberg RH (2000) The 1997-98 El Niño evolution relative to previous El Niño events. J Climate 13:488-501

Williams TD (1995) The Penguins. Oxford University Press, New York

Wilson RP, Duffy DC, Wilson MPT, Araya B (1995) Aspects of the ecology of species replacement in Humboldt and Magellanic penguins in Chile. Gerfaut 85:49-61

Wooster WS, Sievers HA (1970) Seasonal variations of temperature, drift, and heat exchange in surface waters off the west coast of South America. Limnol Oceanogr 15:595-605

Zavalaga CB, Paredes R (1997) Humboldt penguins at Punta San Juan, Perú. Peng Conserv 10:6-8

Submitted: February 13, 2001; Accepted: May 23, 2001

Proofs received from author(s): January 25, 2002 